\title{
The effect of hippophae rhamnoides extract on oral mucositis induced in rats with methotrexate
}

\author{
Ozan KUDUBAN ${ }^{1}$, Muhammed Recai MAZLUMOGLU², Selma Denktas KUDUBAN ${ }^{3}$, Ertugrul ERHAN ${ }^{4}$, Nihal CETIN $^{5}$, \\ Osman KUKULA ${ }^{6}$, Oguzhan YARALI ${ }^{7}$, Ferda Keskin CIMEN $^{8}$, Murat CANKAYA ${ }^{9}$
}

\footnotetext{
1- Erzurum Education and Research Hospital, Ear Nose and Throat Head\&Neck Surgery Clinic, Erzurum, Turkey.

2- Hinis State Hospital, Department of Otorhinolaryngology, Erzurum, Turkey.

3- Palandoken State Hospital, Department of Plastic Reconstructive and Esthetic Surgery, Erzurum, Turkey.

4- Erzincan University, Faculty of Medicine, Department of Otorhinolaryngology, Erzincan, Turkey.

5- Erzincan University, Faculty of Medicine, Department of Pharmacology, Erzincan, Turkey.

6- Ondokuzmayis University, Faculty of Medicine, Department of Pharmacology, Samsun, Turkey.

7- Erzurum Training and Research Hospital, Department of Medical Genetics, Erzurum, Turkey.

8- Mengucek Gazi Education and Research Hospital, Department of Pathology, Erzincan, Turkey.

9- Erzincan University, Faculty of Arts and Sciences, Department of Biology, Erzincan, Turkey.
}

Corresponding address: Nihal Cetin - Department of Pharmacology, Faculty of Medicine - Erzincan University, 24030 - Erzincan - Turkey - Phone: +90 5556307638 - Fax: +90 4462261819 - e-mail: nihalcetin84@gmail.com

Submitted: March 14, 2016 - Modification: May 12, 2016 - Accepted: May 31, 2016

\section{ABSTRACT}

\begin{abstract}
bjective: To investigate the effect of HRE (Hippophae rhamnoides extract) on oral mucositis induced in rats with MTX. Material and Methods: Experimental animals were divided into groups as healthy (HG), HRE+MTX (HMTX), and control group, which received MTX (MTXC). HMTX group received $50 \mathrm{mg} / \mathrm{kg}$ HRE while MTXC and HG groups received equivolume distilled water with gavage once a day. After one hour of HRE and distilled water administration, HMTX and MTXC groups received a single dose of oral MTX 5 mg/ $\mathrm{kg}$. This procedure was repeated for one month. Results: The levels of MDA, IL-1 $\beta$, and TNF- $\alpha$ were found to be significantly higher in the cheek, lower lip, and tongue tissue of the animals receiving MTX, compared with HG and HMTX groups; however, these parameters were lower in the cheek and low lip tissue, and a milder damage ocurred in these tissues, compared with the tongue tissue in MTXC group. No histopathologic damage was observed in the cheek, lower lip, and tongue tissues of the rats treated with HRE. Conclusion: This findings indicate that HRE as a natural product is an important advantage compared with synthetic drugs for prophylaxis of oral mucositis developed due to MTX.
\end{abstract}

Keywords: Gene expression. Hippophae rhamnoides. Methotrexate. Oral mucositis. Rats.

\section{NTRODUCTION}

Methotrexate (MTX) is an antiproliferative folic acid antagonist used in the treatment of various cancers and chronic inflammatory diseases. Lowdose MTX is used to treat inflammatory diseases and high doses are used to treat malignancies ${ }^{2}$. However, high-dose MTX cause serious adverse effects $^{29}$. MTX and some antineoplastic drugs destruct the proliferating cells of the mucosal layer, creating damage in the oral tissues ${ }^{14}$. This side effect, known as oral mucositis, occurs in $40 \%$ of patients receiving chemotherapy ${ }^{12}$. Mucositis reportedly consists of steps beginning with the formation of reactive oxygen species (ROS), progressing with the release of proinflammatory cytokines, such as tumor necrosis factor (TNF-a) and interleukin-1 beta (IL-1 $\beta$ ), resulting in mucosal damage, infection, and cell death ${ }^{21}$. Oral mucositis causes either discontinuation or reduced chemotherapy dose ${ }^{19,28}$. Therefore, numerous studies have been conducted about protection against mucositis, but there are no specific medications in clinical practice for the treatment of mucositis. MTX has been reported to decrease the glutathione level and to significantly increase levels of myeloperoxidase (MPO), malondialdehyde (MDA), interleukin 1 beta (IL-1 $\beta$ ), and tumor necrosis factor (TNF- $\alpha$ ), which are indicators of inflammatory response in the gastrointestinal 
system ${ }^{1,16}$. This information from the literature indicates that MTX may also damage the oral mucosa, showing antioxidant, antiinflammatory, antiulcer, and antimicrobial effects, and inhibiting the production of proinflammatory cytokines. Hippophae rhamnoides fruit extract (HRE), tested in this study against MTX oral mucositis, showed antioxidant, antiulcerogenic, antiinflammatory, antimicrobial, and proinflammatory cytokine antagonist properties ${ }^{18,27,31}$. Hippophae rhamnoides L. plant, member of the Eleagnaceae family, contains carotenoids $(\alpha, \beta, \gamma)$, riboflavin, vitamin $C$, tocopherol, tocotrienol, folic acid, tannin, and fatty acids ${ }^{18,31}$. No studies on the protective effect of HRE against oral mucositis induced by MTX were found in the literature screening. Therefore, the objective of this study is to investigate and evaluate the effect of HRE on oral mucositis induced in rats with MTX through biochemical, gene expression, and histopathologic examinations.

\section{MATERI AL AND METHODS}

\section{Animals}

Experimental animals were obtained from Atatürk University Medical Experimental Application and Research Center. A total of 21 rats weighing 224-232 g were used. Before the experiment, animals were doused and fed as groups ( $n-7)$ in the pharmacology laboratory at normal room temperature $\left(22^{\circ} \mathrm{C}\right)$. The study was conducted in Ataturk University Experimental Studies and Research Center, Erzurum. The experimental procedure was approved by the Committee for Animal Research of Ataturk University, Erzurum. This study was carried out in accordance with international guidelines on the ethical use of animals. (Ethics Committee Number: 23.10.2015/168).

\section{Chemical agents}

The chemical agents used in the experiment were methotrexate supplied from Med-İlaç-Turkey, Thiopental sodium from I.E. Ulagay-Turkey, and Hippophea rhamnoides extract from Karen BilimTurkey.

\section{The experiment}

Experimental animals were divided into groups as healthy (HG), HRE+MTX (HMTX), and control group, which received MTX (MTXC). HMTX group of rats (n7) was given $50 \mathrm{mg} / \mathrm{kg}$ HRE while MTXC ( $\mathrm{n}-7)$ and HG ( $n-7)$ groups were given equivolume distilled water with gavage once a day. After one hour of HRE and distilled water administration, HMTX and MTXC groups received a single dose of oral MTX $5 \mathrm{mg} / \mathrm{kg}$. This procedure was repeated for one month. At the end of this period, all animals were sacrificed with high-dose anesthesia. Then the amounts of MDA and tGSH were determined in the removed cheek, lower lip, and tongue tissues. In addition, IL- $1 \beta$ and TNF- $\alpha$ gene expressions were measured, and all the tissues were histopathologically studied.

\section{Biochemical analyses \\ MDA analysis}

According to the method defined by Ohkawa, et al. ${ }^{22}$ (1979), MDA forms a pink complex with thiobarbituric acid (TBA) at $95^{\circ} \mathrm{C}$, which can be measured using spectrophotometry at a wavelength of $532 \mathrm{~nm}^{22}$. The volume of $0.1 \mathrm{~mL}$ homogenat was added to a solution containing $0.1 \mathrm{~mL}$ of $8.1 \%$ sodium dodecyl sulphate (SDS), $1.5 \mathrm{~mL}$ of $20 \%$ acetic acid (Merck, Darmstadt, Hessen, Germany) $1.5 \mathrm{~mL}$ of $0.9 \%$ TBA (Sigma-Aldrich, Steinheim,

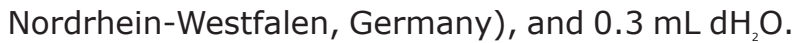
The mixture was incubated at $95^{\circ} \mathrm{C}$ for $1 \mathrm{~h}$. Upon cooling, $5 \mathrm{~mL}$ of $\mathrm{n}$-butanol: pyridine ( $\mathrm{v} / \mathrm{v}, 15: 1$, Merck, Darmstadt, Hessen, Germany) was added. The mixture was vortexed for $1 \mathrm{~min}$ and centrifuged for $30 \mathrm{~min}$ at $4000 \mathrm{rpm}$. The absorbance of the $0.15 \mathrm{~mL}$ supernatant was measured at $532 \mathrm{~nm}$ by spectrophotometry. The Standard curve was obtained by using 1,1,3,3-tetramethoxypropane (Sigma-Aldrich, Steinheim, Nordrhein-Westfalen, Germany).

\section{tGSH analysis}

According to the method defined by Sedlak, et al. ${ }^{25}$ (1968), DTNB [5,5'-dithiobis (2-nitrobenzoic acid)] disulfite is chromogenic in the medium, and DTNB is reduced easily by sulfhydryl groups. The yellow color produced during the reduction is measured by spectrophotometry at $412 \mathrm{~nm}^{25}$. For measurement, cocktail solution $[5.85 \mathrm{~mL}$ $100 \mathrm{mM}$ Na-Fosfat buffer, $2.8 \mathrm{~mL} 1 \mathrm{mM}$ DTNB (Sigma-Aldrich, Steinheim, Nordrhein-Westfalen, Germany), 3.75 mL 1 mM NADPH (Sigma-Aldrich, Steinheim, Nordrhein-Westfalen, Germany), and 80 $\mu \mathrm{L} 625$ U/L Glutathione reductase (Sigma-Aldrich, Steinheim, Nordrhein-Westfalen, Germany)] was prepared. Before measurement, $0.1 \mathrm{~mL}$ metaphosphoric acid (Sigma-Aldrich, Steinheim, Nordrhein-Westfalen, Germany) was added onto $0.1 \mathrm{~mL}$ homogenate and centrifuged for $2 \mathrm{~min}$ at $2000 \mathrm{rpm}$ for deproteinization. The volume of $0.15 \mathrm{~mL}$ cocktail solution was added onto $50 \mu \mathrm{L}$ of supernatant. The Standard curve was obtained using GSSG (Sigma-Aldrich, Steinheim, NordrheinWestfalen, Germany).

\section{Gene expression of IL-1 $\beta$ and TNF- $\alpha$}

RNA isolation: RNA was isolated from the homogenizated oral tissue samples using the Roche Magna Pure Compact LC device (Roche Diagnostics $\mathrm{GmbH}$, Meinheim, Germany) with MagNA MagNA Pure LC RNA Kit (Roche Diagnostics GmbH, Mannheim, Germany). The quantity and quality of 
the isolated RNA were assessed with a nucleic acid measurement device (Maestro, Nano, Nucleotest Bio Ltd. 1038 Budapest, Hungary). Fifty $\mu \mathrm{L}$ of RNA samples were stored at $-80^{\circ} \mathrm{C}$.

cDNA synthesis: cDNA was synthesized from the isolated RNA samples using the Transcriptor First Strand cDNA synthesis kit (Roche Diagnostics $\mathrm{GmbH}$, Mannheim, Germany). For each subject, 1 $\mu \mathrm{LddH} \mathrm{O}_{2} \mathrm{O}, 10 \mu \mathrm{L} \mathrm{RNA}$, and $2 \mu \mathrm{L}$ Random Primer were combined and incubated in Thermal Cycler for 10 min at $65^{\circ} \mathrm{C}$. After incubation, $4 \mu \mathrm{L}$ Reaction Buffer, $0.5 \mu \mathrm{L}$ RNAase, $2 \mu \mathrm{L}$ Deoxynucleotide Mix, and 0.5 $\mu \mathrm{L}$ Reverse Transcriptase were added; the reactions were incubated for $10 \mathrm{~min}$ at $25^{\circ} \mathrm{C}, 30 \mathrm{~min}$ at $55^{\circ} \mathrm{C}$, $5 \mathrm{~min}$ at $85^{\circ} \mathrm{C}$, then held at $4^{\circ} \mathrm{C}$.

Quantitative gene expression evaluation by real-time polymerase chain reaction (RT-qPCR): For each cDNA sample, gene expression of both MPO and reference gene (G6PD) was analyzed using the Roche LightCycler 480 II Real-Time PCR instrument (Roche Diagnostics GmbH, Meinheim, Germany).
PCR reactions in a final volume of $20 \mu \mathrm{L}: 5 \mu \mathrm{L} C D N A$, $3 \mu \mathrm{L}$ distiled water, $10 \mu \mathrm{L}$ LightCycler 480 Probes Master (Roche Diagnostics GmbH, Mannheim, Germany), and $2 \mu \mathrm{L}$ primer-probe set (Real-Time Ready single assay - Roche Diagnostics $\mathrm{GmbH}$, Mannheim, Germany). Cycle conditions of the relative quantitative PCR ( $\mathrm{PPCR}$ ) were preincubated at $95^{\circ} \mathrm{C}$ for $10 \mathrm{~min}$, followed by 45 amplification cycles of $95^{\circ} \mathrm{C}$ for $10 \mathrm{~s}, 6^{\circ} \mathrm{C}$ for $30 \mathrm{~s}, 72^{\circ} \mathrm{C}$ for $1 \mathrm{~s}$, followed by cooling at $40^{\circ} \mathrm{C}$ for $30 \mathrm{~s}$. qPCR analysis and calculation of quantification cycle (Cq) values for Relative Quantification were performed using the LightCycler 480 Software, Version 1.5 (Roche Diagnostics GmbH, Mannheim, Germany). Relative quantitative amounts were calculated by dividing the target genes by the expression level of the reference gene. Reference gene was used for normalization of target gene expression.

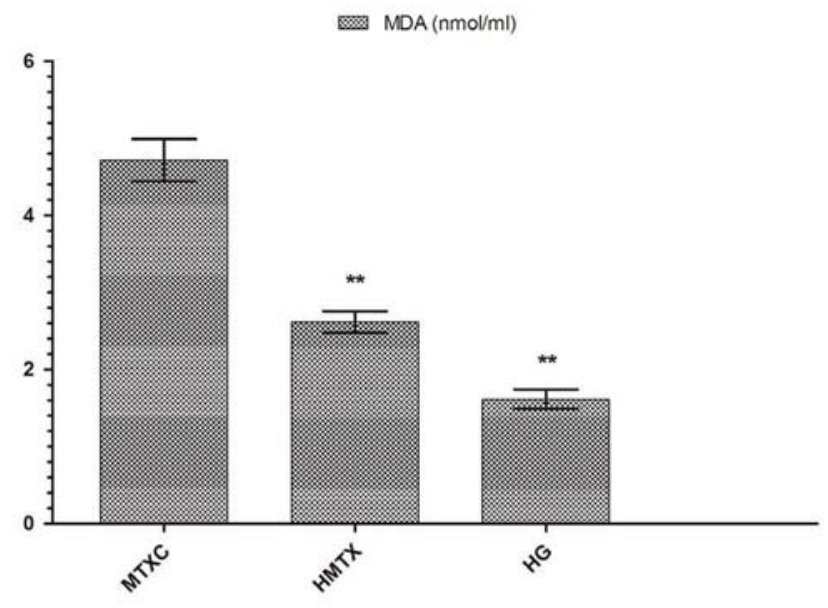

Figure 1a

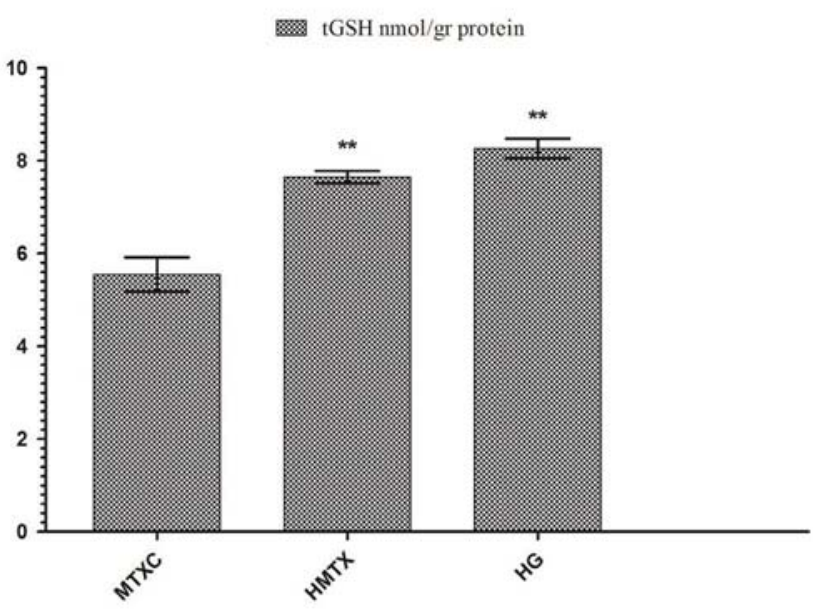

Figure 1b

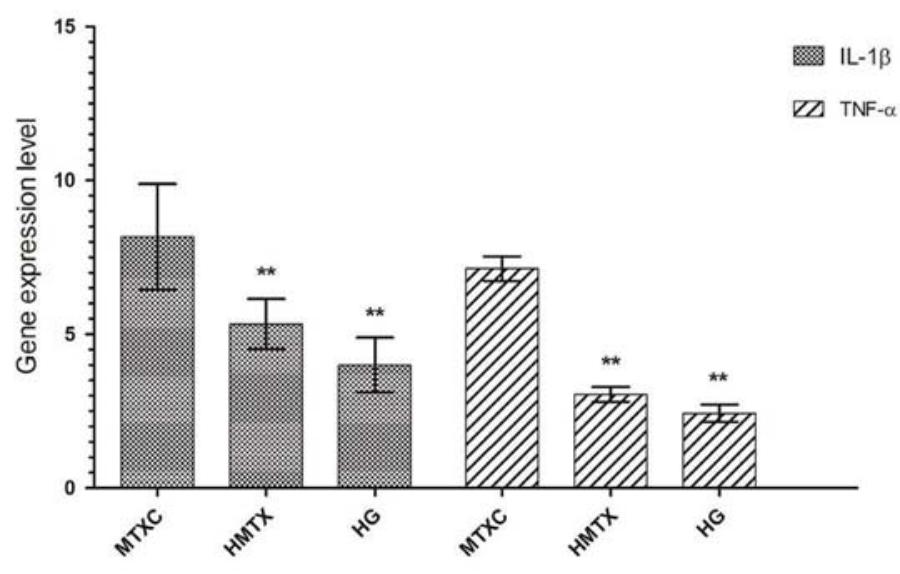

Figure 1c

Figure 1- a: The effects of methotrexate on malondialdehyde (MDA) levels in the cheek mucosal tissues; b: The effects of methotrexate on tGSH levels in the cheek mucosal tissues; c: The effects of methotrexate on IL-1 $\beta$ gene expression level in the cheek mucosal tissues. ${ }^{*} p<0.0001$ 


\section{Histopathologic examination}

The cheek mucosa, lower lip, and tongue tissues removed from the animals were fixed in $10 \%$ formalin solution for $24 \mathrm{~h}$. Following routine tissue processing, paraffin blocks were cut into 4 $\mu \mathrm{m}$ thick sections and stained with hematoxylin and eosin (H\&E). All the sections were evaluated by a pathologist who was blinded to the treatment protocols under optic microscope (BX-52; Olympus, Tokyo, Japan).

\section{Statistical analysis}

Experimental results were expressed as "mean \pm standard error" ( $x \pm$ SEM). Significance of the difference between the groups was determined using one-way ANOVA test followed by LSD test. All statistical analyses were performed using the SPSS Statistics Version 22 statistical software, and $p$ value $<0.05$ was considered significant.

\section{RESULTS}

\section{Biochemical results}

Figure 1a shows that the amounts of MDA were determined as $4.71 \pm 0.66,2.61 \pm 0.34$, and $1.61 \pm 0.30 \mu \mathrm{mol} / \mathrm{gr}$ protein, and the amounts of tGSH were found as $5.55 \pm 0.90,7.65 \pm 0.32$, and $8.26 \pm 0.51 \mathrm{nmol} / \mathrm{gr}$ protein in the cheek mucosal tissues of MTXC, HMTX, and HG groups; respectively (Figure 1b). MDA values were found as 5.18 \pm 0.55 , $3.11 \pm 0.29$, and $2.00 \pm 0.41$ (Figure $2 a$ ) and, tGSH values were found as $5.83 \pm 0.49,8.05 \pm 0.53$, and $10.25 \pm 0.59 \mathrm{nmol} / \mathrm{gr}$ protein in the lower lip tissues of MTXC, HMTX, and HG groups; respectively (Figure $2 b$ ). The amounts of MDA were measured as $9.23 \pm 0.46,3.31 \pm 0.47$, and $2.80 \pm 0.40 \mu \mathrm{mol} /$ gr protein in the tongue tissues of MTXC, HMTX, and HG groups (Figure 3a). Whereas, the amount of tGSH were found as $1.78 \pm 0.33,6.81 \pm 0.37$, and $7.38 \pm 0.46 \mathrm{nmol} / \mathrm{gr}$ protein in the tongue tissues of these groups (Figure $3 b$ ).

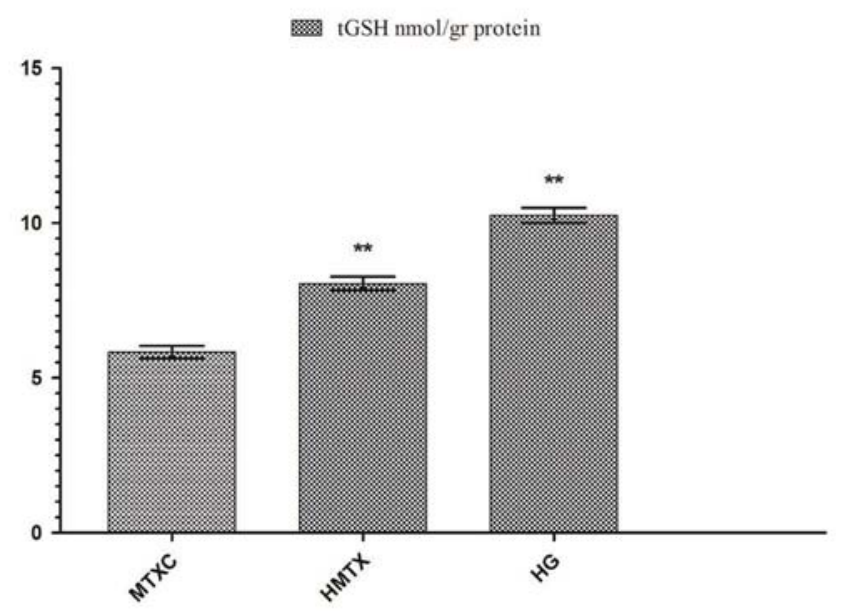

Figure $2 b$

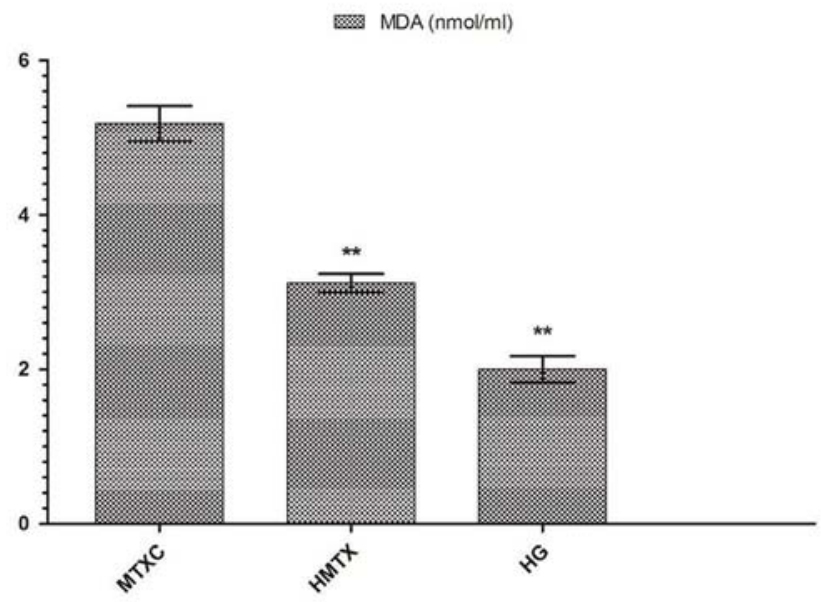

Figure 2a

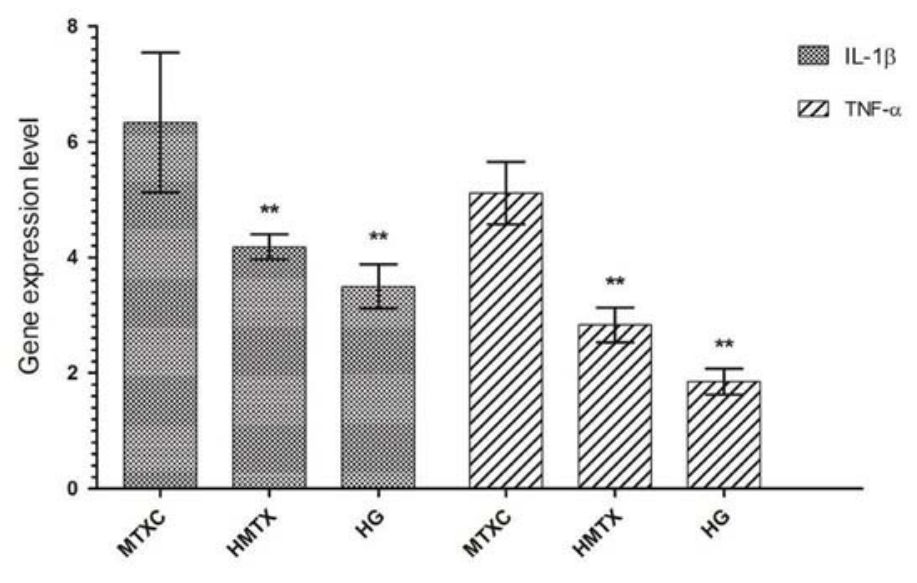

Figure 2c

Figure 2- $a$ : The effects of methotrexate on malondialdehyde (MDA) levels in the lower lip tissues; $b$ : The effects of methotrexate on tGSH levels in the lower lip tissues; c: The effects of methotrexate on IL-1 $\beta$ gene expression level in the lower lip tissues. ${ }^{*} p<0.0001$ 


\section{Gene expression results}

Orally administered MTX raised IL-1 $\beta$ gene expression in the cheek tissue of rats to $8.16 \pm 1.72$. This rate was found as $5.33 \pm 0.81$ and $4.00 \pm 0.89$ in HMTX and HG groups. Again, MTX raised TNF- $\alpha$ gene expression in the cheek tissue of rats to 7.13 \pm 0.40 , while HRE reduced TNF- $\alpha$ gene expression to $3.05 \pm 0.24$. This rate was measured as $2.43 \pm 0.28$ in $\mathrm{HG}$ group (Figure $1 \mathrm{c}$ ). IL-1 $\beta$ gene expression in the lower lip tissue was found as $6.33 \pm 1.21,4.18 \pm 0.21$, and $3.50 \pm 0.38$, and TNF- $\alpha$ gene expression was measured as $5.11 \pm 0.54$, $2.83 \pm 0.30$, and $1.85 \pm 0.22$ in MTXC, HMTX, and HG, respectively (Figure $2 \mathrm{c}$ ). Similarly, MTX significantly increased IL-1 $\beta$ and TNF- $\alpha$ gene expressions in the tongue tissue compared with HMTX and HG. IL$1 \beta$ expression in the tongue tissue was found as $16.16 \pm 2.78,5.35 \pm 0.76$, and $2.98 \pm 0.24$ and, TNF-a

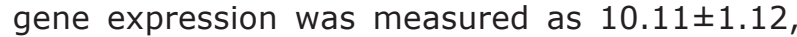
$2.73 \pm 0.39$, and $2.00 \pm 0.58$ in MTXC, HMTX, and $\mathrm{HG}$; respectively (Figure $3 \mathrm{c}$ ).

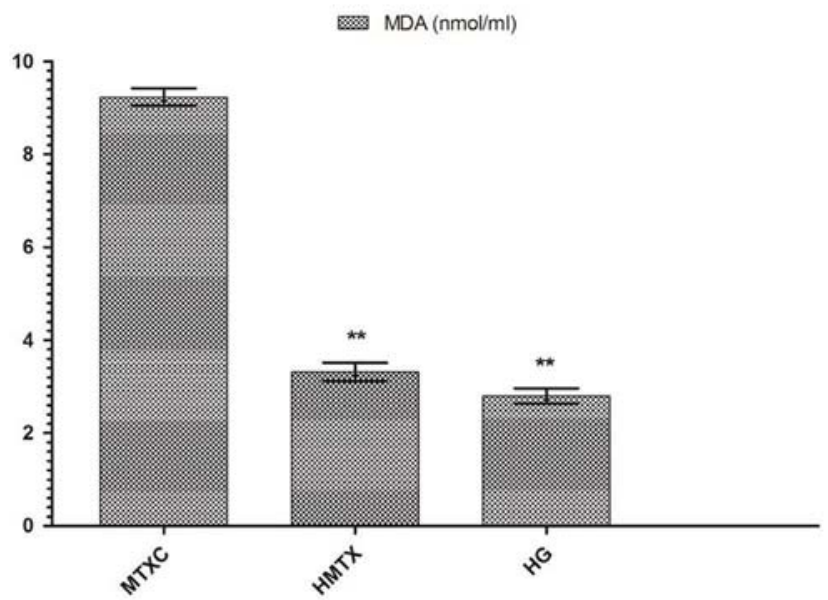

Figure $3 a$

\section{Histopathologic results}

Examinations under optic microscope revealed a normal histopathologic appearance of the cheek, lower lip, and tongue tissues of the healthy group (Figure 4a, 4b, and 4c).

In Figure $4 d$, dilated congested blood vessels (arrow) and edema (star) were distinguished in the cheek mucosal tissue of MTXC group, which received MTX, while there were mild edema (star) and dilated congested blood vessels (arrow) observed also in the lower lip mucosa of this group (Figure 4e). However, besides dilated congested blood vessels (Figure 4f), fibroblastic proliferation (star) and fat cells replaced muscle layer (arrow) were also monitored in the tongue mucosal tissue of MTXC group (Figure $4 \mathrm{~g}$ ). Additionally, dilated congested proliferated blood vessels (Figure 4h) and marked edema (star) were found in the tongue tissue of MTXC group (Figure $4 i)$. No pathologic finding was observed in the cheek, lower lip, and tongue tissues of the animals treated with HRE (Figure 4j, 4k, 4l).

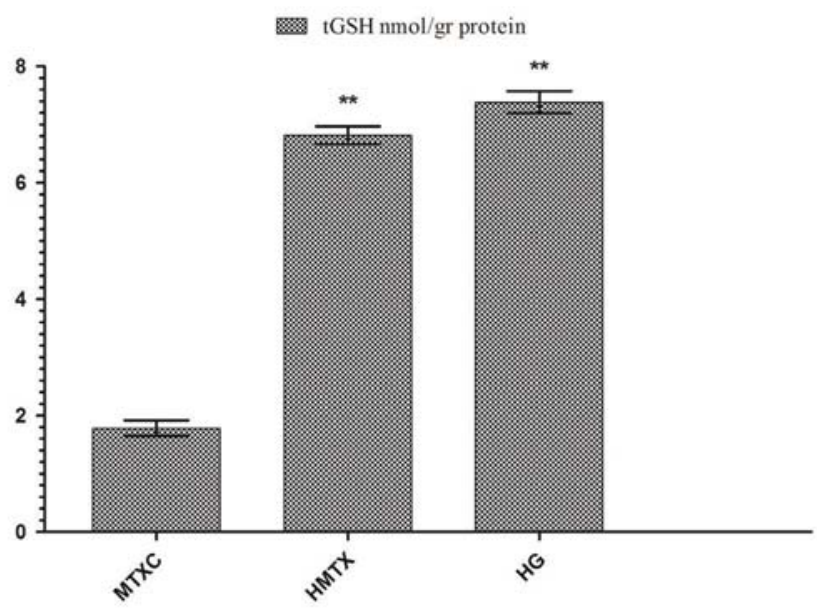

Figure $3 b$

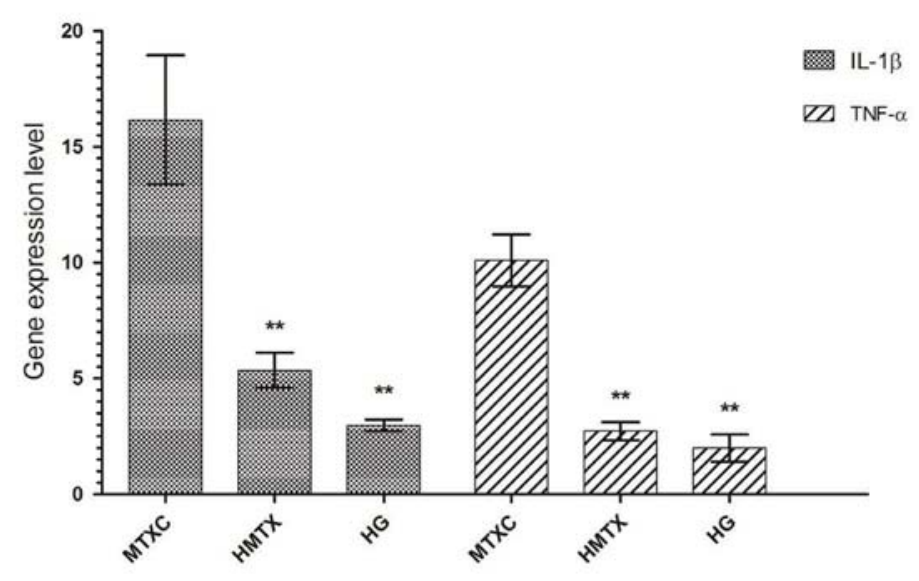

Figure $3 c$

Figure 3- a: The effects of methotrexate on malondialdehyde (MDA) levels in the tongue tissues; b: The effects of methotrexate on tGSH levels in the tongue tissues; c: The effects of methotrexate on IL-1 $\beta$ gene expression level in the tongue tissues. ${ }^{*} \mathrm{p}<0.0001$ 


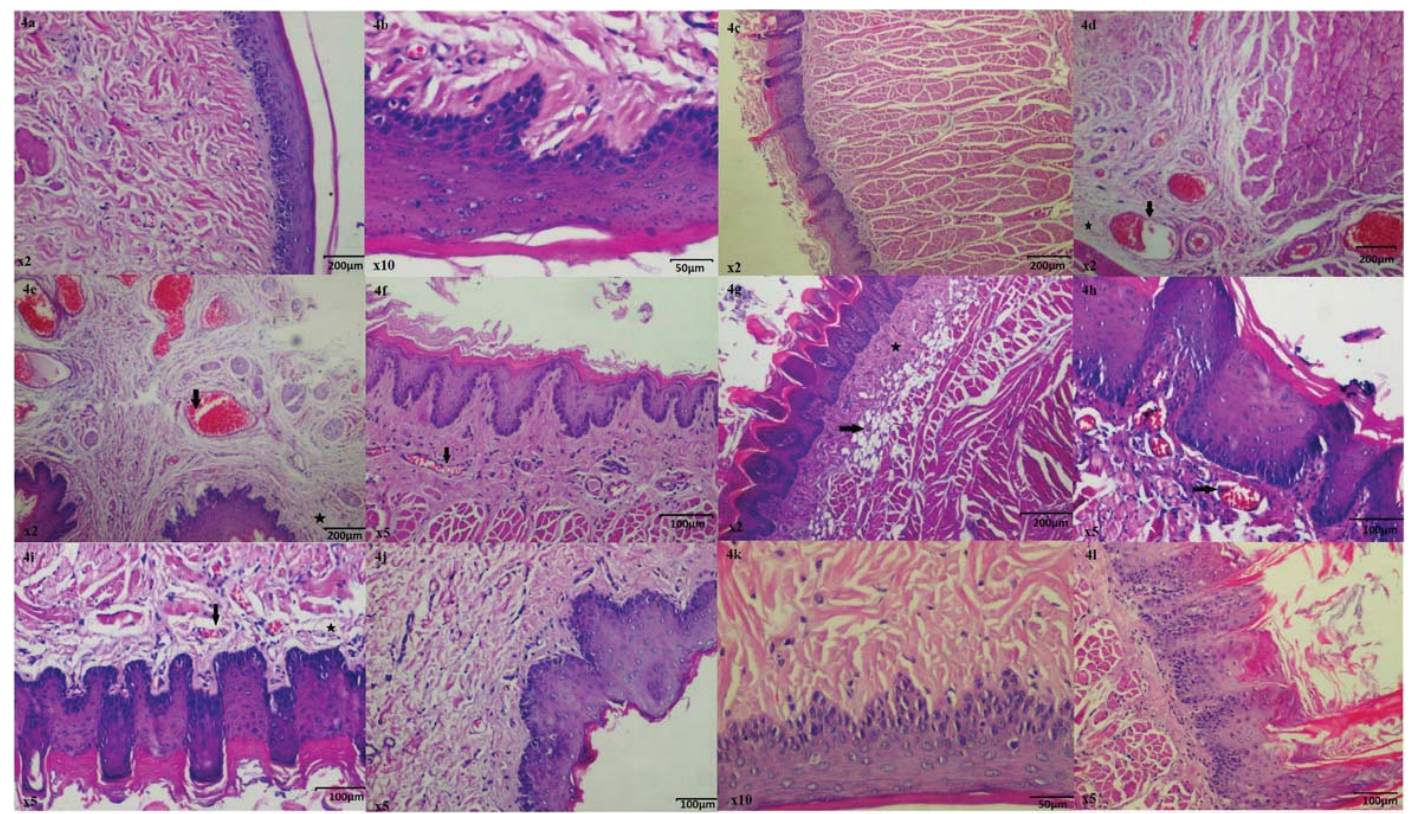

Figure 4- a: Normal histopathologic appearance of the rat cheek tissue of Healthy Group (HG) (HE\&40); b: Normal histopathologic appearance of the rat cheek tissue of HG (HE\&20); c: Normal histopathologic appearance of the rat cheek tissue of HG (HE\&40); d: Dilated congested blood vessels (arrow) and edema (star) are distinguished in the cheek mucosa of MTXC group given methotrexate (MTX) (HEx40); e: Mild edema (star) and dilated congested blood vessels (arrow) are monitored in the lip mucosa of MTXC group given MTX (HEX40); $f$ : Dilated congested blood vessels are seen in the tongue mucosa of MTXC group given MTX (HE\&100); g: Fibroblastic proliferation (star) and fat cells replaced muscle layer are monitored in the tongue mucosal tissue of MTXC group given MTX (arrow) (HE\&40); h: Dilated, congested, proliferated blood vessels (arrow) are seen in the tongue mucosa of MTXC group given MTX (HE\&100); i: Edema (star) and dilated congested blood vessels (arrow) are monitored in the tongue mucosal tissue of MTXC group given MTX (HE\&100); j: Appearance of the cheek tissue of HMTX group treated with Hippophae rhamnoides extract (HRE) resembling normal mucosa (HEx10); k: Appearance of the lip tissue of HMTX group treated with HRE resembling normal mucosa (HEx20); I: Appearance of the tongue tissue of HMTX group treated with HRE resembling normal mucosa (HEx100)

\section{SCUSSI ON}

In this study, the effect of HRE on oral mucositis induced in rats with MTX was investigated and evaluated through biochemical, gene expression, and histopathologic examinations. Experimental results showed that the amount of MDA was increased and the amount of tGSH was decreased in the cheek, lower lip, and tongue tissues of the rats given MTX. Furthermore, IL- $1 \beta$ and TNF- $\alpha$ gene expressions were also significantly increased in the tissues in which MDA was significantly increased. MDA is known to be an oxidant and GSH an antioxidant parameter ${ }^{17}$. Therefore, increased MDA and decreased tGSH amounts indicate the development of oxidative stress. MTX has been experimentally demonstrated to increase the tissue levels of MDA, which is a marker of lipid peroxidation to decrease the level of $\mathrm{tGSH}^{15,20}$. HRE, which is used against the toxicity of MTX, was found to significantly prevent the increase of MDA and decrease of tGSH in the cheek, lower lip, and tongue tissues. This demonstrates that HRE protects the tissues against oxidative stress. Fruits of Hippophae rhamnoides contain numerous phytochemicals, such as vitamins A, E, C, carotens, fatty acids, and flavonoids ${ }^{10,18,31}$. These antioxidant phytochemicals are used to treat cancer, ulcer, liver, and skin diseases ${ }^{32}$. Many researchers have reported that lipid peroxidation products are increased, and the plasma level of vitamin $E$ is decreased in the tissues of cancer patients due to chemotherapy ${ }^{30}$. Lipid peroxidation products increased with chemotherapy have been reported to decrease free radical scavengers antioxidant vitamins, such as vitamins $A, E$, and $C^{4,26}$. In another in vivo and in vitro study, the use of vitamins $E, A$, and $C$ against oxidative stress caused by chemotherapy has been found to enhance the therapeutic effect and also protect normal cells against apoptosis ${ }^{5}$. It has been reported in a cell culture and animal model that the combinations of vitamins A, B6, B12, C, D, and E with $\beta$-caroten protected against adverse effects of chemotherapy prolonged survival time and increased response to treatment ${ }^{26}$. Furthermore, it has been argued in a study evaluating riskbenefit ratio of $\beta$-caroten, vitamin $E$, vitamin $C$, and multivitamin combinations that vitamins had 
protective effect in cancer patients at risk ${ }^{6}$. This information from the literature indicates that our experimental results were in parallel with previous studies.

In this study, we also found that IL- $1 \beta$ and TNF- $\alpha$ gene expressions in the cheek, lower lip, and tongue tissues were significantly increased in the rats given MTX, compared with healthy and HRE groups. Chang CT noted that the levels of proinflammatory cytokines, such as IL- $1 \beta$ and TNF- $\alpha$, were elevated in the oral tissue with mucositis developed due to chemotherapy ${ }^{8}$. Another study shows that the levels of IL-1 $\beta$ and TNF- $\alpha$ were increased and inflammatory ulcers were developed in the intestinal tissue with $\mathrm{MTX}^{3}$. In this study, IL- $1 \beta$ and TNF- $\alpha$ gene expressions were significantly increased in the tissues in which MDA was significantly increased. No information was found in the literature about the role of IL-1 $\beta$ and TNF- $\alpha$ in MTX oral mucositis. However, Çakir, et al. ${ }^{7}$ (2015) reported that MTX induced the amount of MDA and IL-1 $\beta$ and TNF- $a$ gene expressions in the kidney tissue. In our experiment, HRE, which significantly prevented the increase of MDA, also significantly prevented the increase of IL- $1 \beta$ and TNF- $\alpha$ gene expressions. Vitamin C, alpha-tocopherol, and beta-carotens, also found in HRE, are known to have ihibitor effects on proinflammatory cytokines ${ }^{23}$. Again, palmitic, oleic, and linoleic fatty acids appear to exert antiinflammatory effects by inhibiting IL-1 $\beta$ and TNF- $\alpha^{13}$.

Macroscopically, no mucosal ulcerations were found in the cheek, lower lip, and tongue tissues of the animals given MTX. In addition, we found histopathological signs including mild edema and dilated congested blood vessels in the cheek and lower lip tissues, which have lower levels of MDA, IL-1 $\beta$, and TNF- $\alpha$ than the tongue tissue. However, marked congested blood vessels, fibroblastic proliferation, fat cells replaced muscle layer, proliferated blood vessels, and edema were observed in the tongue mucosal tissue.

No pathologic findings were monitored in the cheek, lower lip, and tongue tissues of the healthy and HMTX groups, suggesting that histopathologic results were consistent with biochemical and gene expression results. Vascular congestion, inflammation, and fibroblastic proliferation are among the histopathologic findings of mucositis ${ }^{11}$. Nothing was found in the literature about excessive fat accumulation in the muscle layer due to MTX. However, several studies associate the accumulation of fat cells with inflammation and demonstrating this is a pathologic event ${ }^{9}$. Edema caused by MTX in the cheek, lower lip, and tongue tissue might be a result of vascular changes. In the literature, edema is one of the histopathologic findings accompanying vascular changes ${ }^{24}$. In conclusion, in this study we demonstrated with biochemical, gene expression, and histopathologic findings that MTX caused mild damage in the cheek and lower lip tissues and more severe damage in the tongue tissue of rats.

HRE was found to protect the cheek, lower lip, and tongue tissue against the toxic effect of MTX. These findings suggest that HRE may be useful for the prophylaxis of oral damage due to MTX.

\section{ACKNOWLEDGMENTS}

We would like to thank Dr. Halis Suleyman.

\section{SCLOSURE}

The authors declare no potential conflict of interests regarding the authorship and/or publication of this article.

\section{REFERENCES}

1- Alamir I, Boukhettala N, Aziz M, Breuillé D, Déchelotte $P$, Coëffier $M$. Beneficial effects of cathepsin inhibition to prevent chemotherapy-induced intestinal mucositis. Clin Exp Immunol. 2010;162(2):298-305.

2- Altindag Ö, Küçükoglu B. Intoxication due to high dose methotrexate in a patient with rheumatoid arthritis: a case report. Turk J Rheumatology. 2011;26(1):58-61.

3- Araújo AA, Borba PB, Souza FH, Nogueira AC, Saldanha TS, Araújo $T E$, et al. In a methotrexate-induced model of intestinal mucositis, olmesartan reduced inflammation and induced enteropathy characterized by severe diarrhea, weight loss, and reduced sucrose activity. Biol Pharm Bull. 2015;38(5):746-52.

4- Bairati I, Meyer F, Gélinas M, Fortin A, Nabid A, Brochet F, et al. A randomized trial of antioxidant vitamins to prevent second primary cancers in head and neck cancer patients. J Natl Cancer Inst. $2005 ; 97(7): 481-8$.

5- Blumenthal RD, Lew W, Reising A, Soyne D, Osorio L, Ying Z, et al. Anti-oxidant vitamins reduce normal tissue toxicity induced by radio-immunotherapy. Int J Cancer. 2000;86(2):276-80.

6 - Borek C. Dietary antioxidants and human cancer. Integr Cancer Ther. 2004;3(4):333-41.

7- Çakir T, Polat C, Baştürk A, Gül M, Aslaner A, Durgut H, et al. The effect of alpha lipoic acid on rat kidneys in methotrexate induced oxidative injury. Eur Rev Med Pharmacol Sci. 2015;19(11):2132-9. 8- Chang C-T, Hsiang CY, Ho TY, Wu CZ, Hong HH, Huang YF. Comprehensive assessment of host responses to 5 -fluorouracilinduced oral mucositis through transcriptomic analysis. PloS One. 2015;10(8):e0135102.

9- Cilla M, Peña E, Martínez MA. Mathematical modelling of atheroma plaque formation and development in coronary arteries. J R Soc Interface. 2014;11(90):20130866.

10- Fatima T, Kesari V, Watt I, Wishart D, Todd JF, Schroeder WR, et al. Metabolite profiling and expression analysis of flavonoid, vitamin $\mathrm{C}$ and tocopherol biosynthesis genes in the antioxidantrich sea buckthorn (Hippophae rhamnoides L.). Phytochemistry. 2015;118:181-91.

11- Freire MR, Freitas R, Colombo F, Valença A, Marques AM, Sarmento VA. LED and laser photobiomodulation in the prevention and treatment of oral mucositis: experimental study in hamsters. Clin Oral Investig. 2014;18(3):1005-13

12- Hejna M, Köstler W, Raderer M, Steger G, Brodowicz T, Scheithauer $W$, et al. Decrease of duration and symptoms in chemotherapy-induced oral mucositis by topical GM-CSF: results of a prospective randomised trial. Eur J Cancer. 2001;37(16):19942002. 
13- Hua KF, Hsu HY, Su YC, Lin IF, Yang SS, Chen YM, et al. Study on the antiinflammatory activity of methanol extract from seagrass Zostera japonica. J Agric Food Chem. 2006;54(2):306-11.

14- Ilgenli T, Ören $H$, Uysal $K$. The acute effects of chemotherapy upon the oral cavity: prevention and management. Turk J Cancer. 2001;31:93-105.

15- Jahovic N, Çevik H, Şehirli AÖ, Yeğen BÇ, Şener G. Melatonin prevents methotrexate-induced hepatorenal oxidative injury in rats. J Pineal Res. 2003;34(4):282-7.

16- Jahovic N, Şener G, Çevik H, Ersoy Y, Arbak S, Yeğen BÇ. Amelioration of methotrexate-induced enteritis by melatonin in rats. Cell Biochem Funct. 2004;22(3):169-78.

17- Kisaoglu A, Borekci B, Yapca OE, Bilen H, Suleyman H. Tissue damage and oxidant/antioxidant balance. Eurasian J Med 2013;45(1):47-9

18- Kwon DJ, Bae YS, Ju SM, Goh AR, Choi SY, Park J. Casuarinin suppresses TNF- $\alpha$-induced ICAM-1 expression via blockade of NF-KB activation in HaCaT cells. Biochem Biophys Res Commun. 2011;409(4):780-5.

19- McGowan D. Chemotherapy-induced oral dysfunction: a literature review. Br J Nurs. 2008;17(22):1422-6.

20- Miyazono Y, Gao F, Horie T. Oxidative stress contributes to methotrexate-induced small intestinal toxicity in rats. Scand J Gastroenterol. 2004;39(11):1119-27.

21- Niscola P, Romani C, Cupelli L, Scaramucci L, Tendas A, Dentamaro $\mathrm{T}$, et al. Mucositis in patients with hematologic malignancies: an overview. Haematologica. 2007;92(2):222-31. 22- Ohkawa H, Ohishi N, Yagi K. Assay for lipid peroxides in animal tissues by thiobarbituric acid reaction. Anal Biochem.1979;95(2):351-8.

23- Oliveira BF, Veloso CA, Nogueira-Machado JA, Moraes EN, Santos RR, Cintra MT, et al. Ascorbic acid, alpha-tocopherol, and beta-carotene reduce oxidative stress and proinflammatory cytokines in mononuclear cells of Alzheimer's disease patients. Nutr Neurosci. 2012;15(6):244-51.
24- Scully C, Bagan JV. Adverse drug reactions in the orofacial region. Crit Rev Oral Biol Med. 2004;15(4):221-39.

25- Sedlak J, Lindsay RH. Estimation of total, protein-bound, and nonprotein sulfhydryl groups in tissue with Ellman's reagent. Anal Biochem. 1968;25:192-205.

26- Simone CB $2^{\text {nd }}$, Simone NL, Simone V, Simone CB. Antioxidants and other nutrients do not interfere with chemotherapy or radiation therapy and can increase kill and increase survival, part 1. Altern Ther Health Med. 2007;13(1):22-8.

27- Süleyman $H$, Demirezer $L$, Büyükokuroglu $M$, Akcay $M$, Gepdiremen A, Banoglu Z, et al. Antiulcerogenic effect of Hippophae rhamnoides L. Phytother Res. 2001;15(7):625-7.

28- Thomson PJ, Greenwood M, Meechan JG. General medicine and surgery for dental practitioners. Part 6 - cancer, radiotherapy and chemotherapy. Br Dent J. 2010;209(2):65-8.

29- Vanhoecke B, Bateman E, Mayo B, Vanlancker E, Stringer A, Thorpe $D$, et al. Dark Agouti rat model of chemotherapy-induced mucositis: establishment and current state of the art. Exp Biol Med. 2015;240(6):725-41.

30- Weijl N, Cleton F, Osanto S. Free radicals and antioxidants in chemotherapyinduced toxicity. Cancer Treat Rev. 1997;23(4):20940.

31- Yilmaz I, Demiryilmaz I, Sener E, Cetin N, Ucuncu Y, Altuner $D$, et al. The effect of Hippophae rhamnoides extract on oxidative damage on rat's gastric tissue depending on coimplementation of methotrexate and indomethacin. Lat Am J Pharm. 2014;33(3):453-8.

32- Zeb A. Chemical and nutritional constituents of sea buckthorn juice. Pakistan J Nutrition. 2004;3(2):99-106. 